\title{
Globalizing Vocational and Technical Education Curriculum for Sustainable Development in Nigeria
}

Ochedikwu, John Ochinyabo

Vocational and Technical Education Department Benue State University, Makurdi-Nigeria

Ukuma, Solomon

Department of Technical Education, College of Education, Katsina-Ala, Nigeria

\section{Attah, Margaret Enotse}

School of Vocational Stuudies, College of Advanced and Professional Studies, Makurdi-Nigeria

\section{Doi:10.5901/jesr.2013.v3n8p63}

\section{Abstract}

The paper is on globalizing vocational and technical education for sustainable development in Nigeria. The paper examines globalizing vocational technical education curriculum to enhance national growth and productivity in Nigeria. The paper also discussed sustainable scientific and technological development in Nigeria through revamping vocational and technical education and training for sustainable development. Finally, the paper has drawn conclusion with suggestions/recommendations on the need for government to take concrete measures to globalize and upgrade our vocational and technical education skills, techniques, knowledge and attitudes through the leaching/learning of vocational and technical education in our institutions of learning for sustainable development.

Keywords: Globalizing, Vocational Technical Education, Curriculum, Sustainable Development

\section{Introduction}

Globally, vocational and technical education is accepted as the acquisition of practical skills, attitudes, knowledge that is applicable to various trades or occupations for the advancement of social and sound economic life of the citizens. The best legacy to beneath to citizens is sound technical education skills, techniques and knowledge. In this $21^{\text {st }}$ century it is quite obvious that, skills techniques and knowledge is the greatest asset to possess. Durosoro (2006) opined that, the traditional sources of wealth like gold, oil and other merchandises have already given way to thoughts and ideas. Mr. Bill gate, the richest man on the surface the earth today, did not by knowledge, skills techniques and ideas of information communication technology (ICT). Durosaro maintained that, Japan, Malaysia and India are making billions of United States Dollars by exporting computer software rather than oil, cassava or gold. Indeed, this is a century of skills, techniques and knowledge and no one should be under the illusion that without knowledge he or she can hope to survive talk less of thrive.

Vocational and Technical Education in Nigeria should adequately provide the desired sound 
technical education to the citizens in Nigeria because the entire education system appears to be in crisis. There is the crisis of technical education funds and finances management, and crisis in teaching technical education institutions of learning. The problems of technical education are problems of every individual or house hold either directly or indirectly. The teachers, students, parents, Government at all levels should know the future developments, challenges and prospects.

\section{Vocational Technical Education}

According to Olaitan, Nwanchukwu, Igbo, Onyemachi and Ekong (1999) affirmed that, vocational technical education is education for work. It can be made available only for those who need it, because they are interested in it and also hope to progressively continue to participate in it. It is meant for those who can profit by it because they hope to sell the skills acquired through occupations and make a living. In vocational technical education technical teachers expose learners to learning in job related situations using functional teaching models in an environment that depicts real work situations.

National Policy on Education NPE (2004) stated that, vocational technical education is used as a comprehensive term referring to those aspects of the education, the study of technologies and related sciences and the acquisition of practical skills, attitudes, understanding and knowledge relating to occupations in various sectors of economic and social life.

Ogwu and oranu (2006) confirmed that, vocational technical education enables all types of learner to have lifelong education and to develop maximum self-potentials. Vocational technical education impart relevant skills for employment, to these groups of Nigerians, they will be enabled to play their roles in the development of the nation.

Also the thrust of vocational technical education is to prepare students or Nigerians with occupational skills that lead to employment in their chosen careers or depending upon their individual goals. Furthermore, vocational technical education purpose is to provide students or citizens with skills they will need to obtain entry-level employment or to pursue further education after graduation.

\section{Sustainable Scientific and Technological Development in Nigeria through Revamping Technical and Vocational Education and Training (TVET) for Sustainable Development}

Sustainable Scientific and Technological Development in Nigeria through technical vocation and training (TVET) is significant and timely when we compare Nigeria (TVET) of developed or advanced or industrialized countries like Japan, United States of America, Germany and China we are really infants in technical and vocational sub sector. Technical and vocational education teacher's minds should begin to revolve up to the point of suggesting new ways of beefing up our technical and vocational education programmes to conform to global standard so as to actualize vision 20:2020 and other transformation programmes.

Siegel (2008) noted thus;

technical education and vocational education teachers should be involved in the following equality of instruction such as local exhibition, cooperating with various industries improvement of reading through technical and vocational education, field trips, updated technical and vocational education curriculum, recruitment of technical and vocational teachers and students clubs.

Revamping technical and vocational education in Nigeria would bring about many ideas, techniques, skills and professional suggestions to revitalize much of what technical and vocational education teachers and stake holders are doing in technical and vocational education to create a 
climate or renitence that would surpass all that we or they accomplished in the past 52 years of independence. The Nigerian youths need to be encourage and motivated to attend institutions of learning and read technical and vocational courses and see tangible evidence of the need to listen, learn skills, techniques and aspire to make or produce or construct things of items selves. They need more direct activity for shear motivation. They learn by as John Dewey said many years ago which is still valid.

Similarly, Olaitan, Nwachukwu, Igbo, Onyemachi and Ekong (1999) stated that;

The present state of effectiveness of vocational and technical education is education for work and therefore, all human and materials resources required for the successful execution of this education should be given adequate attention by the government and policy makers. Since this attention has not been provided for the needed improvement of the available human and material resources the state of effectiveness of technical and vocational education has remained very low, and remain so until adequate attention is given to it.

It is worthy to note that, until vocational and technical is revamped by means of manpower development, adequate funding, changes of technical and vocational education teachers attitudes towards their jobs, students attitudes towards technical and vocational education courses, trainee interest, retention and achievement, motivation of technical and vocational education teachers to mention but a few. This would be achieved by adopting good measures at various levels of government begin to bear fruits. If technical and vocational education is not revamped we would continued to observed sharp rise in business failures, unemployment and fall in the Nigeria industries, companies and factories declaring record losses.

Also, Ogwo and Oranu (2006) revealed that;

Technical and vocational education when effectively handled will help in conserving and developing the vast natural resources available in the country. Given adequate technical and vocational training, Nigeria will be able to look inward and exploit the local materials resources as well as traditional inequality of ours. By the skillful adoption and creative invention of technology artifacts, one can genuinely describe a technology as Nigeria. These are some of the things the effectively organized technical and vocational education can help the country to achieve.

Revamping technical and vocational education would open the door to investors; it would lift a burden from the neck of Nigerians and would stabilize the economy. Nigeria government need to found or invest in considerable amount of money to achieve our independence in all sectors of the economy, such as importation of vehicles spare parts, fuel, food (rice) and other consumable goods. If technical and vocational education is not revamped, Nigerian's0 would not avoid all the hazards consequences of using sub-standard products or items that are been produced by China and other developed and underdeveloped nations.

Nigeria, the giant of Africa may ran into a major glitch or problems, the consequences of which may still be suffering in years ahead because of non-revamping of technical and vocational education since 1960. The result is moderate decline in the production of qualified technical and vocational teachers, lack of machines, workshops or laboratories, lack of infrastructures etc. revamping technical and vocational education would urgently make Nigeria to be debt free, significantly saving Nigeria from heavy interest and penalty payments and it had to go through in the past, at present and future if technical and vocational education is revamped it would enhance national growth sustainable development and productivity in all sectors of the Nigerian economy. 


\title{
4. Globalizing Vocational Technical Education Curriculum to Enhance National Growth and productivity in Nigeria
}

It is necessary for Nigeria to advance through globalizing vocational technical education curriculum to make her vocational and technical education curriculum very relevant through training and retraining of vocational technical education teachers in all the course or trades in vocational technical education and the acquisition of teaching and learning facilities for rapid growth and productivity.

This could be confirmed by Lall and Teubal (2001) when they argue that;

\begin{abstract}
Globalizing vocational and technical education curriculum for growth and productivity would enhance scientific and technological development which would be based on learning and stimulating. This process requires the setting of priorities, identification of linkages and selection of technological promotion. This requires an overall vision of where the economy should or could be heading. A failure of coordination amongst skills and techniques, policy can prevent an economy from achieving a higher development path. This is because moving into new activities and adopting new technology requires sufficient good quality and appropriately skilled workers with new technologies involves learning and acquiring practical experience as well as informal skills.
\end{abstract}

Similarly, Dirk (2001) maintained that:

Globalizing vocational technical curriculum has meant an increase in the development of technology, technology flows across countries and increased fragmentation of production processes worldwide. This has required an ever greater need for information flows to manage and take part in the process of globalization. Lack of information is precisely at the heart of market and coordination failures. So in times when technology moves faster and faster around the world, there is an increased need to be up to date with the latest needs for human resources development in order to solve market failures which would prevent a match between demand and supply of skills.

Globalizing vocational technical curriculum is very important in the competitiveness in the global labour market. Appropriate training of Nigeria in skills acquisition will enable Nigeria and other developing countries to achieve the transformation of our workforce skills to match our economic, political, social, scientific and technological transformation. Globalizing vocational technical education curriculum would complement by a sophisticated and modern skills training system and lifelong learning.

Globalizing vocational technical education curriculum for national growth and productivity can only be effective in Nigeria if vocational technical education is practice as it is practice in developed nations like United States of America (USA), Japan, and Germany. But in Nigeria, vocational and technical education is totally dependent on the expertise and facilities of other developed nations. Non globalizing of vocational technical education curriculum would create a threat to the achievement of the Seven point Agenda of the Federal Government and Vision 20:2020

Similarly, Johansen and Adams (2004) said that:

Globalizing vocational technical education curriculum and reviewed skills development in SubSaharan Africa, which is on the whole very different from skills development in other regions. Management and finance provide powerful instruments for promoting reforms in vocational and technical education.

Nigeria at 52 years should craved for vocational technical education that could lead us to growth, productivity and development so as to reduce poverty and accomplish government 
strategic plans in all sectors of the economy for sustainable development strategic plans in all sectors of the economy for sustainable development. Nigeria, the Giant of Africa has not achieve any meaningful development in the vocational and technical education sector because of the neglect of vocational and technical education. This has greatly affected growth and productivity in all the sectors of our economy. Therefore, Nigeria would continue to lag behind in all the aspects of human endeavour and the eight Millennium Development Goals (MDGs), Sven point Agenda and vision 20:2020 all these would be a mirage or difficult to achieve if vocational and technical education is not give the desired attention.

But vocational technical education is the base or stratum which all the sectors of the economic hinge on for development in developed and developing countries. Getting vocational technical education curriculum globalized like developed Nations for efficient and rapid growth and productivity is an important first step in revamping vocational technical education for national growth and productivity.

We need to globalize our vocational technical education curriculum in all Nigerian vocational and technical education institutions in tune with highly industrialized countries curriculum so as to produce better quantity and quality vocational technical education graduates in Nigeria.

\section{Conclusion}

Globalizing vocational technical education for national growth and productivity in Nigeria require urgent government, stakeholders in vocational and technical education and the private sector intervention. Based on the above, discussion the following conclusions has been drawn:

* It is important and necessary to restructure and globalize vocational technical education curriculum in various educational programmes or courses in institutions of learning that link in with the demand of the citizenry.

* Vocational technical education curriculum globalizing should be undertaken urgently for the purpose of relevance and participate effectively at the global labour market and Nigeria would not be depending on other developing and developing and developed countries for assistance on all the sectors of the economy for national growth and productivity.

\section{Recommendations/Suggestions}

Government should motivate vocational and technical education teachers by giving them incentives so as to improve the standard of training to remain competitive in the global labour market.

$>$ Vocational and technical education should be given more attention, funds should be allocated to vocational and technical education hence globally, emphasis is on skill acquisition, education for scientific and technological self reliant because vocational and technical education affects social status of Nigeria.

$>$ Hence vocational technical education is hinged on skills, knowledge and attitudes upgrading for national growth and productivity, vocational technical education institutions should be equipped, staffed with qualified vocational technical education teachers and new vocational technical education institutions should be establish in Nigeria to upgrade fresh graduates, old workers so that they may be highly productive and this would enhance national growth also.

\section{References}

Dirk, W.T. (2001) Globalization and Education; what do the trade investment and migration literatures tell us? London overseas Development institute III Westminster bridge Road Publishers. 
Durosaro, D.O. (2006) Teacher Education in Nigeria: Past Present and Future challenges. J ournal of Oyo State College of Education 13, 43-53

Federal Republic of Nigeria (2004) National Policy on Education; Lagos Nigerian Educational Research and Development Council Publishers.

J ohansen, R.K. and Adams, A.V. (2004) Skills Development in Sub-Sahara Africa; Washington D.C. World Bank.

Lall, S. and Teubal, M. (2001) Market Stimulating Technology Policies in Developing Countries; London's Macmillan Publishers.

Ogwu, B.A. and Oranu, R.N. (2006) Methodology in formal and Non-formal Technical Vocational Education; Nsukka, University of Nigeria Press Limited.

Olaitan, S.O., Nwachukwu, C.E.; Igbo, C.O. Onyemachi G.A.; Ekong, A.O. (1999) Curriculum Development and Management in Vocational Technical Education: Onitsha, Cape Publishers International Limited.

Siegel, H. (2008) The role of the Vocational Teacher as a leader in the Urban setting. Journal of man Society Technology 6,16-21 